\title{
COMMON BEAN CULTIVARS AND LINES INTERACTIONS WITH ENVIRONMENTS
}

\author{
Sérgio Augusto Morais Carbonell ${ }^{1 *}$; Joaquim Adelino de Azevedo Filho ${ }^{2}$; Luiz Antônio dos \\ Santos Dias ${ }^{3}$; Antonio Augusto Franco Garcia ${ }^{4}$; Lizz Kezzy de Morais ${ }^{5}$ \\ IAC/APTA - Centro de Análise e Pesquisa Tecnológica do Agronegócio dos Grãos e Fibras, C.P. 28 - 13001-970 \\ - Campinas, SP - Brasil. \\ ${ }^{2}$ DDD/APTA - Pólo Regional do Leste Paulista, C.P. 11 - 13910-000 - Monte Alegre do Sul, SP - Brasil. \\ ${ }^{3}$ UFV/BIOAGRO - 36571-000 - Viçosa, MG - Brasil. \\ ${ }_{5}^{4}$ USP/ESALQ - Depto. de Genética, C.P. 83 - 13400-970 - Piracicaba, SP - Brasil. \\ ${ }^{5}$ UFG/Escola de Agronomia - Setor de Melhoramento Vegetal, C.P. 131 - 74001-970 - Goiânia, GO - Brasil. \\ *Corresponding author <carbonel@iac.sp.gov.br>
}

\begin{abstract}
The performance of bean lines brought forth in breeding programs or of cultivars in use can be affected by environmental variability. The adaptability and stability of grain yield of 18 common bean cultivars and lines in 23 environments (combinations of seasons, years and locations) were evaluated in the State of São Paulo, Brazil. 'IAC-Carioca' and 'IAC-Carioca Eté' were used as standard cultivars for the carioca grain type, while 'FT-Nobre' and 'IAC-Una' represented the standard for black grains. The experiment was set up in a randomized complete block design with four replications and plots consisting of two, two central five meters rows flanked by border rows. Stability parameters were estimated by the methods Maximum Yield Deviations (MYD) and by the Additive Main Effects and Multiplicative Interaction Analysis (AMMI). For the identification of the most stable cultivars, the two methods led to consistent results, although by MYD the highest stability was always associated to the highest yield. 'MAC-733327' and 'LP 9637' were the most suitable cultivars and lines for the joint seasons, while 'LP 9637' and 'FT-Nobre' were the most suitable for the dry season. The MYD method combined a simple procedure, easiness of result interpretation, uniqueness of parameters, and association between stability and yield. On the other hand, the AMMI method simplified the identification of stable cultivars by visual inspection, also providing information on the environments. However, the complex nature which combines uni- and multivariate techniques hampers its widespread use in breeding programs.
\end{abstract}

Key words: Phaseolus vulgaris, AMMI, adaptability, stability, cultivar

\section{INTERAÇÕES DE CULTIVARES E LINHAGENS DE FEIJOEIRO COM AMBIENTES}

\begin{abstract}
RESUMO: A variabilidade de ambientes pode afetar o desempenho de linhagens de feijoeiro geradas nos programas de melhoramento e também dos cultivares em uso. Assim, foram avaliadas a adaptabilidade e a estabilidade de produção de grãos de 18 cultivares e linhagens de feijoeiro em 23 ambientes (combinações de épocas, anos e locais), no Estado de São Paulo. 'IAC-Carioca' e 'IAC-Carioca Eté' foram os cultivares usados como padrões de grãos tipo carioca, enquanto 'FT-Nobre' e 'IAC-Una' foram padrões para grãos pretos. Os ensaios foram instalados em blocos completos casualizados, com quatro repetições e parcela útil de duas linhas centrais de cinco metros. Os parâmetros de estabilidade foram estimados pelos métodos dos Desvios da Produtividade Máxima (MYD) e da Análise da Interação Multiplicativa e dos Efeitos Principais Aditivos (AMMI). Ambos produziram resultados congruentes em termos de identificação dos cultivares mais estáveis, porém a maior estabilidade esteve sempre associada à maior produtividade no MYD. 'MA733327' e 'LP 9637' foram os cultivares mais indicados para o conjunto das épocas, águas e inverno, enquanto LP 9637 e FT-Nobre foram os mais estáveis na seca. MYD reuniu simplicidade de procedimento, facilidade de interpretação de resultados, unicidade de parâmetros e associação entre estabilidade e produtividade. Por sua vez, AMMI, além de informar sobre os ambientes, facilitou a identificação dos cultivares estáveis por inspeção visual. Porém sua fundamentação complexa, visto que combina técnicas uni e multivariadas, dificulta seu uso generalizado em programas de melhoramento.

Palavras-chave: Phaseolus vulgaris, AMMI, adaptabilidade, estabilidade, cultivares
\end{abstract}

\section{INTRODUCTION}

Brazil is an outstanding producer and consumer of common bean (Phaseolus vulgaris L.). Combined with rice, common bean is Brazilians' principal source of plant proteins. Common bean is a traditional crop now cultivated according to newly introduced technologies. In the State of São Paulo, for instance, it is cultivated during 
three seasons: rainy, dry and winter, with sowings between August and October, January and March, and April and May, respectively, according to the ecological zoning of the crop (Pinzan et al., 1994).

The common bean is cultivated in a great variability of environments. Knowledge on the performance of new lines brought forth by breeding programs and the cultivars in use is determinant for the success of the crop. Studies on adaptability and yield stability of cultivars and lines have pointed to the importance of the interaction between genotypes and environments (GE interaction) and, as a consequence, the variable behavior of these genotypes according to different locations, years, and cultivation periods (Ramalho et al., 1993; Carbonell \& Pompeu, 2000).

In bean breeding programs, the identification of "strategic sites" for the selection, based on GE interactions and using data on grain productivity and reaction to diseases, is also important. Strategic sites have been investigated in the States of São Paulo (Carbonell \& Pompeu, 1997), Minas Gerais (Abreu et al., 1992), and Goiás (Duarte \& Zimmermann, 1991).

Aiming the selection and recommendation of new cultivars, statistical methodologies have been used for various crops to evaluate genotype behavior in different environments. For the common bean, Carbonell et al. (2001) applied two methodologies to evaluate the adaptability and stability of 12 cultivars in 24 environments of the State of São Paulo, during 1997 and 1998. According to these authors, the method of Lin \& Binns (1988), modified by Carneiro (1998), presented the most informative and consistent results than the Cruz et al. (1989) method, which suggested that the most stable and responsive cultivars were also the most productive.

The use of uni-multivariate method called Additive Main Effects and Multiplicative Interaction Analysis - AMMI (Gauch \& Zobel, 1996) was proposed for studies involving adaptability and phenotypic stability (Duarte \& Venkovsky, 1999). According to Gauch \& Zobel (1996), AMMI can help to identify highly productive and broadly adaptable genotypes, and perform the socalled ecological regionalization, to establish region specific recommendations.

A total of 18 bean cultivars and lines, participants of the State Evaluation System, were evaluated in this study, aiming at a registration by the Ministério da Agricultura, Pecuária e Abastecimento - MAPA (Ministry of Agriculture, Animal Husbandry, and Supply) and the recommendation of cultivars. Phenotypic adaptability and stability analyses were carried out by the method of Lin \& Binns (1988), modified by Carneiro (1998), and by AMMI, in 23 environments (combinations of seasons, locations, and years of cultivation), and the efficiency of these methods was also discussed.

\section{MATERIAL AND METHODS}

Trials

Experiments for the evaluation of the 18 cultivars and lines were set up in 1999 and 2000, in the main bean producing regions of São Paulo, Brazil, during the rainy, dry, and winter seasons (Table 1). The experimental design consisted of randomized complete block design, with four replications. Each plot contained four rows, five meter long, $0.60 \mathrm{~m}$ between rows (in winter), $0.50 \mathrm{~m}$ (rainy and dry), and $0.20 \mathrm{~m}$ along the row, with three seeds per pit. Two out of three plants per pit were left after thinning (60 plants per row). Only the two central rows of each plot were harvested. The experimental management (fertilization, thinning, crop spraying, and harvest) was made as described by Carbonell et al. (2001).

\section{Data analyses}

'IAC-Carioca' (carioca), 'IAC-Carioca Eté' (carioca), 'IAC-Una' (black) and 'FT-Nobre' (black) were used as standard cultivars and compared to others, using the Dunnett test $(\alpha=0.05)$. Joint variance analyses were carried out for grain productivity per sowing season and for the combined seasons (Table 2). Homogeneity analyses of variance were performed through the Hartley test. When necessary, degrees of freedom were adjusted according to Cochran (1954). Analyses of grain productivity stability were processed by the methods of Maximum Yield Deviations (MYD) (Linn \& Binns, 1988, modified by Carneiro, 1998) and by Additive Main Effects and Multiplicative Interaction Analysis (AMMI) (Gauch \& Zobel, 1996). The analytical procedure was carried out with the help of the softwares GENES (Cruz, 2001) for MYD, and SAS (SAS Institute, 1989) for AMMI.

The genotype performance $\left(\mathrm{P}_{\mathrm{i}}\right)$ was estimated for MYD as the mean square of the distance between the cultivar mean and the highest mean response of each environment. Since this maximum response is at the upper limit of each environment, the lowest mean square (lowest $\left.P_{i}\right)$ indicates the general superiority of the cultivar in study. This superiority mean is calculated by (1):

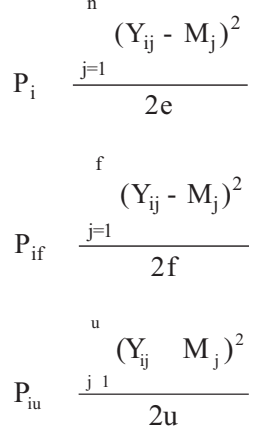

where $\mathrm{P}_{i}$ is the estimate of the parameter of cultivar $i$, designated genotypic performance; $\mathrm{Y}_{\mathrm{ij}}$ is the cultivar i pro- 
ductivity in the environment $\mathrm{j}$; $\mathrm{M}$ is the highest response obtained among all cultivars in environment $j$; and $e, f$, and $\mathrm{u}$ express the total number of environments, favorable and unfavorable, respectively.

However, to obtain cultivar recommendations which include the aspect of favorable (f) and unfavorable (u) environment groups, expressing, in a way, environments of high and low technology input, Carneiro (1998) suggested to split $P_{i}$ in two parts, favorable $\left(\mathrm{P}_{\text {if }}\right)$ in (2) and unfavorable $\left(\mathrm{P}_{\mathrm{iu}}\right)$ in (3). The clas- sification of these environments was made based on environmental indices, defined as the difference between the evaluated cultivar mean in each environment and the general experimental mean. Favorable environments (f) are those that present means above or equal to zero, while the unfavorable $(\mathrm{u})$ present negative indices.

AMMI (Gauch \& Zobel, 1996) combines, in a single model, additional components for the main effects of genotypes $\left(\mathrm{g}_{\mathrm{i}}\right)$ and of environments $\left(\mathrm{e}_{\mathrm{j}}\right)$, and multipli-

Table 1 - Cultivars, lines, environments and their respective codes evaluated in the São Paulo State common bean yield trials.

\begin{tabular}{|c|c|c|c|c|c|c|c|c|c|c|}
\hline \multirow{2}{*}{\multicolumn{3}{|c|}{ Cultivars and Lines }} & \multicolumn{8}{|c|}{ Environments (Seasons) } \\
\hline & & & \multicolumn{2}{|r|}{ Rainy } & \multicolumn{2}{|r|}{ Dry } & \multicolumn{2}{|r|}{ Winter } & \multicolumn{2}{|r|}{ Rainy/Dry/Winter } \\
\hline Code & Name & $\begin{array}{l}\text { Grain } \\
\text { type }\end{array}$ & Code & $\begin{array}{c}\text { Environments } \\
\text { (Local-Year) }\end{array}$ & Code & $\begin{array}{l}\text { Environments } \\
\text { (Local-Year) }\end{array}$ & Code & $\begin{array}{l}\text { Environments } \\
\text { (Local-Year) }\end{array}$ & Code & $\begin{array}{c}\text { Environments } \\
\text { (Local-Season-Year) }\end{array}$ \\
\hline 1 & FT-Nobre & Carioca & A & Capão Bonito - 1999 & I & $\begin{array}{l}\text { Capão Bonito - } \\
1999\end{array}$ & $\mathrm{O}$ & Tatuí -1999 & I & $\begin{array}{l}\text { Capão Bonito- } \\
\text { Dry - } 1999\end{array}$ \\
\hline 2 & FT-Porto Real & Carioca & B & Mococa-1999 & $\mathrm{J}$ & $\begin{array}{l}\text { Capão Bonito - } \\
2000\end{array}$ & $\mathrm{P}$ & $\begin{array}{l}\text { Votuporanga - } \\
1999\end{array}$ & $\mathrm{O}$ & $\begin{array}{l}\text { Tatuí - Winter - } \\
1999\end{array}$ \\
\hline 3 & FT-901909 & Carioca & $\mathrm{C}$ & $\begin{array}{l}\text { Espírito Santo do } \\
\text { Pinhal - } 1999\end{array}$ & $\mathrm{~K}$ & $\begin{array}{l}\text { Adamantina1 - } \\
2000\end{array}$ & Q & $\begin{array}{l}\text { Ribeirão Preto - } \\
1999\end{array}$ & $\mathrm{P}$ & $\begin{array}{l}\text { Votuporanga - } \\
\text { Winter -1999 }\end{array}$ \\
\hline 4 & GenC97-2 & Carioca & $\mathrm{D}$ & Taquarituba - 1999 & $\mathrm{~L}$ & $\begin{array}{l}\text { Adamantina2 - } \\
2000\end{array}$ & $\mathrm{R}$ & $\begin{array}{l}\text { Pindamonhangaba- } \\
1999\end{array}$ & Q & $\begin{array}{l}\text { Ribeirão Preto - } \\
\text { Winter - } 1999\end{array}$ \\
\hline 5 & GenC97-3 & Carioca & $\mathrm{E}$ & $\begin{array}{l}\text { Monte Alegre do Sul- } \\
2000\end{array}$ & M & $\begin{array}{l}\text { Espírito Santo do } \\
\text { Pinhal - } 2000\end{array}$ & $\mathrm{~S}$ & Pindorama - 1999 & $\mathrm{R}$ & $\begin{array}{l}\text { Pindamonhangaba - } \\
\text { Winter - } 1999\end{array}$ \\
\hline 6 & GenC97-7 & Carioca & $\mathrm{F}$ & Capão Bonito - 2000 & $\mathrm{~N}$ & Itapeva - 2000 & $\mathrm{~T}$ & Pindorama - 2000 & $\mathrm{~S}$ & $\begin{array}{l}\text { Pindorama - } \\
\text { Winter-1999 }\end{array}$ \\
\hline 7 & GenC97-10 & Carioca & G & Mococa - 2000 & & & $\mathrm{U}$ & $\begin{array}{l}\text { Adamantina3 - } \\
2000\end{array}$ & A & $\begin{array}{l}\text { Capão Bonito - } \\
\text { Rainy -1999 }\end{array}$ \\
\hline 8 & IAC-Carioca & Carioca & $\mathrm{H}$ & $\begin{array}{l}\text { Espírito Santo do } \\
\text { Pinhal - } 2000\end{array}$ & & & $\mathrm{~V}$ & $\begin{array}{l}\text { Adamantina4 - } \\
2000\end{array}$ & B & $\begin{array}{l}\text { Mococa - } \\
\text { Rainy-1999 }\end{array}$ \\
\hline 9 & $\begin{array}{l}\text { IAC-Carioca } \\
\text { Eté }\end{array}$ & Carioca & & & & & $\mathrm{X}$ & Mococa-2000 & $\mathrm{C}$ & $\begin{array}{l}\text { Espírito Santo do } \\
\text { Pinhal -Rainy-1999 }\end{array}$ \\
\hline 10 & IAC-Una & Carioca & & & & & & & $\mathrm{D}$ & $\begin{array}{l}\text { Taquarituba - } \\
\text { Rainy -1999 }\end{array}$ \\
\hline 11 & IAPAR-80 & Carioca & & & & & & & $\mathrm{J}$ & $\begin{array}{l}\text { Capão Bonito -Dry- } \\
2000\end{array}$ \\
\hline 12 & IAPAR-81 & Carioca & & & & & & & $\mathrm{K}$ & $\begin{array}{l}\text { Adamantina1 - Dry- } \\
2000\end{array}$ \\
\hline 13 & LM-932042-17 & Preto & & & & & & & $\mathrm{L}$ & $\begin{array}{l}\text { Adamantina2 - Dry- } \\
2000\end{array}$ \\
\hline 14 & LP 9637 & Preto & & & & & & & M & $\begin{array}{l}\text { Espírito Santo do } \\
\text { Pinhal-Dry - } 2000\end{array}$ \\
\hline 15 & LP 9672 & Preto & & & & & & & $\mathrm{N}$ & Itapeva-Dry - 2000 \\
\hline 16 & MA-733327 & Preto & & & & & & & $\mathrm{T}$ & $\begin{array}{l}\text { Pindorama -Winter- } \\
2000\end{array}$ \\
\hline 17 & PF-902998 & Preto & & & & & & & $\mathrm{U}$ & $\begin{array}{l}\text { Adamantina3 - } \\
\text { Winter-2000 }\end{array}$ \\
\hline 18 & Princesa & Preto & & & & & & & $\mathrm{V}$ & $\begin{array}{l}\text { Adamantina4 - } \\
\text { Winter-2000 }\end{array}$ \\
\hline & & & & & & & & & $\mathrm{X}$ & $\begin{array}{l}\text { Mococa-Winter - } \\
2000\end{array}$ \\
\hline & & & & & & & & & $\mathrm{E}$ & $\begin{array}{l}\text { Monte Alegre do } \\
\text { Sul-Rainy - } 2000\end{array}$ \\
\hline & & & & & & & & & $\mathrm{F}$ & $\begin{array}{l}\text { Capão Bonito-Rainy } \\
-2000\end{array}$ \\
\hline & & & & & & & & & $\mathrm{G}$ & $\begin{array}{l}\text { Mococa-Rainy - } \\
2000\end{array}$ \\
\hline & & & & & & & & & $\mathrm{H}$ & $\begin{array}{l}\text { Espírito Santo do } \\
\text { Pinhal-Rainy }-2000\end{array}$ \\
\hline
\end{tabular}

Adamantina: $51^{\circ} 11^{\prime} 59 \mathrm{~W}-21^{\circ} 24^{\prime} \mathrm{S}$; Capão Bonito: $48^{\circ} 36^{\prime} \mathrm{W}-23^{\circ} 50^{\prime} \mathrm{S}$; Espírito Santo do Pinhal: $46^{\circ} 55^{\prime} \mathrm{W}-22^{\circ} 04^{\prime} \mathrm{S}$; Itapeva: $49^{\circ} 15^{\prime} \mathrm{W}$

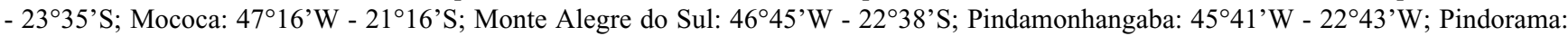
$49^{\circ} 01^{\prime} \mathrm{W}-21^{\circ} 7^{\prime} \mathrm{S}$; Ribeirão Preto: $47^{\circ} 59^{\prime} \mathrm{W}-21^{\circ} 04^{\prime} \mathrm{S}$; Taquarituba: $49^{\circ} 40^{\prime} \mathrm{W}-23^{\circ} 24^{\prime} \mathrm{S}$; Tatui: $48^{\circ} 05^{\prime} \mathrm{W}-23^{\circ} 13^{\prime} \mathrm{S}$ and Votuporanga: $50^{\circ} 11^{\prime} \mathrm{W}-29^{\circ} 19^{\prime} \mathrm{S}$. 
Table 2 - ANOVA for the São Paulo State common bean yield $\left(\mathrm{kg}^{\left.-\mathrm{ha}^{-1}\right)}\right.$ trials. The C/L-E interaction was partitioned to Interaction Principal Component Axes (IPCA) by using AMMI model.

\begin{tabular}{|c|c|c|c|c|c|c|c|c|c|c|c|c|}
\hline \multirow[t]{3}{*}{ Sources } & \multicolumn{12}{|c|}{ Environments (Seasons) } \\
\hline & \multicolumn{3}{|c|}{ Rainy } & \multicolumn{3}{|c|}{ Dry } & \multicolumn{3}{|c|}{ Winter } & \multicolumn{3}{|c|}{ Rainy/Dry/Winter } \\
\hline & $d f$ & MS & $\mathrm{F} / \mathrm{Fr}$ & $d f$ & MS & $\mathrm{F} / \mathrm{Fr}$ & $d f$ & MS & $\mathrm{F} / \mathrm{Fr}$ & Df & MS & $\mathrm{F} / \mathrm{Fr}$ \\
\hline $\begin{array}{l}\text { Replication/ } \\
\text { Trial }\end{array}$ & 24 & 720648.93 & 4.9 & 18 & 539330.34 & 4.18 & 27 & 229934.16 & 1.67 & 69 & 481329.60 & 3.47 \\
\hline $\begin{array}{l}\text { Cultivar/Line } \\
(\mathrm{C} / \mathrm{L})\end{array}$ & 17 & 1138237.69 & $7.73^{* *}$ & 17 & 263836.65 & $2.05^{* *}$ & 17 & 712911.27 & $5.17 * *$ & 17 & 1399777.73 & $10.09 * *$ \\
\hline $\begin{array}{l}\text { Environments } \\
\text { (E) }\end{array}$ & 7 & 27570628.08 & $187.29 * *$ & 5 & 37872404.62 & $293.85^{* *}$ & 8 & 42652071.71 & $309.6 * *$ & 22 & 33521973.92 & $241.63 * *$ \\
\hline $\mathrm{C} / \mathrm{L} \times \mathrm{E}^{1 /}$ & 93 & 633681.09 & $4.3^{* *}$ & 85 & 253385.02 & $1.97 * *$ & 105 & 288519.77 & $2.09 * *$ & 291 & 396639.03 & $2.86 * *$ \\
\hline IPCA 1 & 23 & 1272587.04 & $8.64 * *$ & 21 & 391108.00 & $3.03 * *$ & 24 & 658329.56 & $4.78 * *$ & 38 & 1045194.12 & $7.53^{* *}$ \\
\hline $\begin{array}{l}\text { Residual } \\
\text { AM M I } 1\end{array}$ & 70 & 480778.25 & $3.27 * *$ & 64 & 208208.38 & $1.61^{*}$ & 81 & 240279.00 & $1.74 * *$ & 253 & 332872.72 & $2.40 * *$ \\
\hline IPCA 2 & 21 & 1151490.04 & $7.82 * *$ & 19 & 260314.60 & $2.02 * *$ & 22 & 408923.04 & $2.97 * *$ & 36 & 844795.00 & $6.09 * *$ \\
\hline $\begin{array}{l}\text { Residual } \\
\text { AM M I } 2\end{array}$ & 49 & 292278.94 & $1.99 * *$ & 45 & 186207.98 & $1.44^{*}$ & 59 & 199054.91 & $1.44 *$ & 217 & 271442.04 & $1.96 * *$ \\
\hline IPCA 3 & 19 & 486581.41 & $3.30 * *$ & 17 & 244063.08 & $1.89 *$ & 20 & 353720.20 & $2.57 * *$ & 34 & 528180.60 & $3.81 * *$ \\
\hline $\begin{array}{l}\text { Residual } \\
\text { AM M I } 3\end{array}$ & 30 & 227292.38 & $1.54 *$ & 28 & 151081.67 & 1.17 & 39 & 154864.83 & 1.24 & 183 & 238625.84 & $1.72 * *$ \\
\hline IPCA 4 & 17 & 252786.89 & $1.72 *$ & 15 & 182310.46 & 1.41 & 18 & 297168.69 & $2.16 * *$ & 32 & 407709.06 & $2.94 * *$ \\
\hline $\begin{array}{l}\text { Residual } \\
\text { AM MI } 4\end{array}$ & 13 & 216179.38 & 1.47 & 13 & 115048.46 & 0.89 & 21 & 105605.80 & 0.77 & 151 & 215503.35 & $1.55^{* *}$ \\
\hline IPCA 5 & & & & & & & 16 & 169123.89 & 1.23 & 30 & 397347.95 & $2.86 * *$ \\
\hline $\begin{array}{l}\text { Residual } \\
\text { A M M I } 5\end{array}$ & & & & & & & 5 & 77375.55 & 0.56 & 121 & 188761.50 & $1.36 * *$ \\
\hline IPCA 6 & & & & & & & & & & 28 & 380911.01 & $2.75^{* *}$ \\
\hline $\begin{array}{l}\text { Residual } \\
\text { AM MI } 6\end{array}$ & & & & & & & & & & 93 & 156192.26 & 1.14 \\
\hline IPCA 7 & & & & & & & & & & 26 & 234415.07 & $1.69 *$ \\
\hline $\begin{array}{l}\text { Residual } \\
\text { A M MI } 7\end{array}$ & & & & & & & & & & 67 & 144980.30 & 1.04 \\
\hline IPCA 8 & & & & & & & & & & 24 & 220160.28 & $1.58 *$ \\
\hline $\begin{array}{l}\text { Residual } \\
\text { AM MI } 8\end{array}$ & & & & & & & & & & 43 & 130660.30 & 0.94 \\
\hline IPCA9 & & & & & & & & & & 22 & 230879.87 & $1.66^{*}$ \\
\hline $\begin{array}{l}\text { Residual } \\
\text { A M M I } 9\end{array}$ & & & & & & & & & & 21 & 109460.01 & 0.79 \\
\hline IPCA 10 & & & & & & & & & & 20 & 176119.43 & 1.27 \\
\hline $\begin{array}{l}\text { Residual } \\
\text { A M M I } 10\end{array}$ & & & & & & & & & & 1 & 93588.72 & 0.14 \\
\hline Error $^{1 /}$ & 306 & 147210.28 & & 306 & 128885.25 & & 342 & 137766.77 & & 903 & 138734.55 & \\
\hline M ean & & 2496 & & & 2263 & & & 2473 & & & 2425 & \\
\hline CV\% & & 15 & & & 16 & & & 15 & & & 13 & \\
\hline
\end{tabular}

**, *F-test significant at the $1 \%$ and $5 \%$, respectively.

${ }^{1}$ Degrees of freedom for Pooled Error, C/L-E interaction and its partitions in the dry, rainy and winter seasons and joint seasons were adjusted by COCHRAN (1954)'s method.

cative components for the interaction effect $\left(\mathrm{ge}_{\mathrm{ij}}\right)$ between them. In this model, besides the general mean $(\mu)$ and the Pooled Error $\left(\varepsilon_{\mathrm{ij}}\right)$, the other terms are the result of the interaction matrix $\left.\mathrm{GE}_{(\mathrm{ge})}=\left[(\mathrm{gê})_{\mathrm{ij}}\right)\right]$, using the Analysis of Principal Components (PCA) for this purpose. Consequently, the mean productivity of one genotype $i$ in an environment $\mathrm{j}$ is expressed in (4) as:

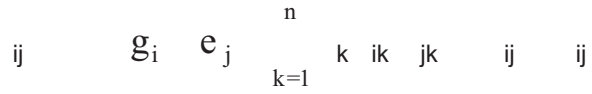

where $Y_{i j}$ is the mean productivity of the genotype $i$ in the environment $\mathrm{j} ; \mu$ is the general mean productivity; $\mathrm{g}_{\mathrm{i}}$ is the effect of the genotype $i ; e_{j}$ is the effect of the environment $\mathrm{j} ; \varepsilon_{\mathrm{ij}}$ is the Pooled Error regarding $\mathrm{Y}_{\mathrm{ij}}$, assumedly independent and normally distributed; $\rho_{\mathrm{ij}}$ is the PCA residue ("noise" portion); $\lambda_{k}$ is the eigenvalue of the PCA axis $\mathrm{k}$, obtained from the matrices $(\mathrm{GE})(\mathrm{GE})$ ' and (GE)'(GE) (of nonzero eigenvalues); $\lambda_{\mathrm{ik}}$ and $\alpha_{\mathrm{jk}}$ are the scores of the principal components of genotype $i$ and environment $\mathrm{j}$, respectively, on the PCA axis $\mathrm{k}$; and $\mathrm{n}$ is the number of axes or the retained principal components to describe the standard GE interaction. 
AMMI recovers the portion of the sum of squares of the $\mathrm{GE}$ interaction $\left(\mathrm{SS}_{\mathrm{GE}}\right)$, which is actually an estimate of interaction, known as "standard" portion, and the "noise" portion, known as residual (Weber et al., 1996). "Standard" stands for the general law of matrix formation which dominates the phenomena of the GE interaction, explained by the $n$ first PCA axes. An investigation of these axes allows the identification of the environmental and genetic factors which are more directly related to the interaction. The noise, present in GE, but not strongly determined by genotypes and environments (matrix lines and columns) is, thus, discarded (Duarte \& Venkovsky, 1999). This approach enhances the prediction capacity of the model.

Not seldom, the choice of the most suitable AMMI model in terms of number of IPCA axes to be retained and able to explain the interaction, is determined by the $\mathrm{SS}_{\mathrm{GE}}$ proportion accumulated up to the $\mathrm{n}^{\text {th }}$ axis $\left(\sum_{k=1}^{n} \lambda_{k}^{2} / S S_{G E}\right)$. For this purpose, the $\mathrm{F}_{\mathrm{r}}$ test of Cornelius et al. (1992) is used as applied by Piepho (1995), who tests the AMMI residual of the IPCA axis. A significant result of the $\mathrm{F}_{\mathrm{r}}$ test suggests that at least one multiplicative term should still be added to the $\mathrm{n}$ already adjusted axes. Once the AMMI model which best describes results is selected, the result of the stability analysis is displayed in the biplot.

Biplots are obtained by combinations of the IPCA scores and capture the standard portion of the GE interaction, since they are able to identify genotypes with tiniest contributions to the interaction (stable); or yet combinations of desirable genotypes and environments in terms of adaptability and stability. Basically, these biplots belong to two types: AMMI 1 and AMMI 2 (Duarte \& Venkovsky, 1999). In AMMI 1, the genotype and environment means are plotted on the abscissa, and the IPCA scores for the same genotypes and environments, on the ordinate. Nevertheless, in AMMI 2, the IPCA scores of the first and second principal components are plotted on the abscissa and ordinate, respectively. For interpretation of the AMMI 1 biplot, the magnitude and signal of the scores of the IPCA1 is observed; scores close to zero are characteristic of genotypes and environments which contribute little to the interaction, that is, they are stable. In a biplot of AMMI 2, the stable genotypes and environments are those that are placed in a circle around the score crossing, close to the origin of the axes.

Although there is no consensus on the minimum proportion of the $\mathrm{SS}_{\mathrm{GE}}$ that must be accumulated by the first IPCA axis for presentation of the biplot, the visual inspection is convenient. According to Duarte \& Venkovsky (1999), biplots have been presented with first axes which accumulated a proportion between 27.1 and $71 \%$. In this study, the $\mathrm{F}_{\mathrm{r}}$ test results were presented (Table 3), although, because of its excessive rigorism, it was decided to present the biplots in those cases where the first IPCA axis accumulated over $25 \%$ of the $\mathrm{SS}_{\mathrm{GE}}$ and offered a similar order of cultivars and lines as the MYD method, independently of the significance of the $F_{r}$ tests. Furthermore, for better visual display, the AMMI 1 biplots were presented under omission of the environments.

\section{RESULTS AND DISCUSSION}

Individual analyses of variance were carried out for the 23 environments (Table 1). A high significance for cultivars, environments, and for the GE interactions was revealed by the joint analyses of variance for each planting season separately, and in the set (Table 2). It is therefore possible, taking the differential behavior in the included environments into consideration, to select the most stable and productive cultivars and lines. An experimental coefficient of variation $\left(\mathrm{CV}_{\mathrm{e}}\right)$ equal to or under $16 \%$ can also be observed in the analyses in relation to single and joint seasons and mean productivities above $2,260 \mathrm{~kg} \mathrm{ha}^{-1}$, demonstrating a good experimental precision and high yield potential of the evaluated cultivars and lines. $\mathrm{CV}_{\mathrm{e}}$ values and mean productivities of the same magnitude were reported by Carbonell et al. (2001).

The relation of the mean seasonal productivity (either one by one or joint) (Table 3) allows the identification of line MA-733327, for winter, and the lines LP 9637 and, again, MA-733327 for the joint seasons, as superior. The mean grain productivity in the dry season $\left(2,263 \mathrm{~kg} \mathrm{ha}^{-1}\right)$ was $9 \%$ lower than the one obtained in the rainy season $\left(2,496 \mathrm{~kg} \mathrm{ha}^{-1}\right)$ and in the winter $(2,473$ $\left.\mathrm{kg} \mathrm{ha}^{-1}\right)$. The smaller productivity during the dry season can be probably attributed to the occurrence of high temperatures during flowering and pod formation, giving rise to aborting of flowers and pods. On the other hand, the highest grain productivity obtained during the rainy season and the winter is probably a consequence of regular rainfalls throughout the entire crop cycle of the rainy season, and the artificial irrigation applied during winter.

Estimates of adaptability and stability parameters obtained by the MYD method (Table 3) for cultivar and line recommendations for a broad range of environments (the three seasons together), show that the lines MA733327 and LP 9637 and the cultivars FT-Porto Real and IAPAR- 80 are the most stable $\left(<\mathrm{P}_{\mathrm{i}}\right.$ and $\left.<\mathrm{P}_{\mathrm{iu}}\right)$ and responsive $\left(<\mathrm{P}_{\text {if }}\right)$, only to underscore the four genotypes. These four most stable cultivars and lines also contain the most productive group and can therefore be recommended for all environments presented here.

Regarding the joint seasons in the AMMI method, observing that the first principal component absorbs $26.20 \%$ and that, together with the second, accumulates $46.27 \%$ of the $\mathrm{SS}_{\mathrm{GE}}$, it was possible to present the biplots AMMI 1 and AMMI 2 (Figures $1 \mathrm{G}$ and $1 \mathrm{H}$, respectively). In this case, the most stable and productive cultivars and lines (Figure 1G), in increasing order of productivity and 
decreasing of stability, were FT-Nobre (1), LM-93204217 (13), FT-Porto Real (2), GenC97-2 (4), MA-733327 (16), and LP 9637 (14). The reduced absorption of the interaction by the first principal component might have led to this distortion in the blipot. 'MA-733327', 'LP 9637', and 'FT-Porto Real' were also identified by MYD (Table 3 ) as the most adapted, stable, and most responsive to environmental enhancement, although in decreasing order of stability and productivity.

By the AMMI 2 biplot (Figure 1H), conclusions can be drawn on the most stable environments: MococaRainy-2000 $(G)$, Capão Bonito-Dry-2000 $(J)$, Mococa$1999(B)$, and Adamantina 3-2000 (U). It is also possible to identify strategic environments for a differentiation of the genotypes in the cases: Monte Alegre do Sul-2000 $(E)$, Espírito Santo do Pinhal-Rainy-2000 (H), Capão Bonito-Rainy-2000 $(F)$, and Votuporanga-Winter-1999 $(P)$. Carbonell \& Pompeu (1997) reported on Capão Bonito as a genotype discriminating environment for, mainly, reaction to diseases, and Mococa, as a homogenous and less stressful environment.

For a specific recommendation of adaptation to the rainy season by MYD, lines MA-733327 and LP
9637, and the cultivar IAPAR-80 were the most outstanding (Table 3), as the most stable $\left(<\mathrm{P}_{\mathrm{i}}\right)$. Line MA733327 and the cultivars IAPAR-80 and IAC-Carioca Eté were most responsive $\left(<\mathrm{P}_{\mathrm{if}}\right)$ to environmental improvements, and lines LP 9637, GenC97-2, and MA733327 most stable in unfavorable environments. By the AMMI 1 biplot (Figure 1A), with the first axis of the IPCA which accumulates $38.80 \%$ of the $\mathrm{SS}_{\mathrm{GE}}$, the most stable and productive cultivars and lines, in decreasing order for stability and increasing order of productivity were FT-Porto Real (2), IAC-Carioca Eté (9), GenC972 (4), MA-733327 (16), and LP 9637 (14). Despite the fact that both methods presented the latter lines as stable, the most stable cultivars and lines identified by AMMI, opposite to the MYD, were again not the most productive, although the absorption of the interaction was greater than in the combination of the seasons. The most differentiating environments of cultivars and lines (Figure 1B) were Monte Alegre do Sul-2000 (E), Espírito Santo do Pinhal-Rainy-2000 $(H)$, and Capão BonitoRainy-2000 (F).

For the dry season, the MYD method identified FT-Nobre, LP9637, and IAPAR-81 (Table 3) as most

Table 3 - São Paulo State common bean yield $\left(\mathrm{kg} \mathrm{ha}^{-1}\right)$ evaluated in 23 environments (combinations of Seasons, Locations and Years. Estimates of stability $\left(\mathrm{P}_{\mathrm{i}}\right)$ were performed by the MYD method, by partitioning it into parts due to favorable $\left(\mathrm{P}_{\mathrm{if}}\right)$ and unfavorable $\left(\mathrm{P}_{\mathrm{iu}}\right)$ environments.

\begin{tabular}{|c|c|c|c|c|c|c|c|c|c|c|c|c|c|c|c|c|}
\hline \multirow{2}{*}{$\begin{array}{l}\text { Cultivars and } \\
\text { Lines }\end{array}$} & \multicolumn{4}{|c|}{ Mean yield $\left(\mathrm{kg} \mathrm{ha}^{-1}\right)$} & \multicolumn{4}{|c|}{$\mathrm{P}_{\mathrm{i}}\left(10^{4}\right)$} & \multicolumn{4}{|c|}{$\mathrm{P}_{\text {if }}\left(10^{4}\right)$} & \multicolumn{4}{|c|}{$\mathrm{P}_{\mathrm{iu}}\left(10^{4}\right)$} \\
\hline & Rainy & Dry & Winter & Joint & Rainy & Dry & Winter & Joint & Rainy & Dry & Winter & Joint & Rainy & Dry & Winter & Joint \\
\hline IAC-Carioca & 1462 & 2195 & 2554 & 2428 & 30.04 & 17.36 & 30.93 & 27.08 & 48.82 & 20.44 & 43.97 & 37.96 & 18.77 & 14.28 & 4.86 & 17.11 \\
\hline $\begin{array}{l}\text { IAC-Carioca } \\
\text { Eté }\end{array}$ & 2602 & 2233 & 2383 & 2420 & 25.89 & 12.81 & 24.63 & 21.99 & 26.92 & 18.44 & 30.59 & 28.68 & 25.27 & 7.18 & 12.72 & 15.85 \\
\hline GenC97-2 & 2640 & 2222 & 2518 & 2483 & 29.32 & 13.09 & 19.08 & 21.08 & 65.33 & 7.78 & 26.29 & 33.58 & 7.72 & 18.41 & 4.68 & 9.63 \\
\hline GenC97-7 & 2428 & 2283 & 2432 & 2392 & 42.33 & 10.62 & 21.04 & 25.73 & 81.77 & 17.31 & 24.86 & 39.03 & 18.67 & 3.93 & 13.41 & 13.54 \\
\hline GenC97-10 & 2363 & 2192 & 2296 & 2292 & 43.32 & 13.97 & 35.96 & 32.79 & 84.08 & 12.04 & 46.71 & 49.62 & 18.86 & 15.91 & 14.48 & 17.36 \\
\hline IAPAR-80 & 2686 & 2235 & 2443 & 2473 & 13.64 & 11.74 & 27.08 & 18.41 & 12.06 & 13.43 & 40.55 & 28.06 & 14.59 & 10.05 & 0.15 & 9.55 \\
\hline IAPAR-81 & 2558 & 2398 & 2431 & 2466 & 27.26 & 7.03 & 23.99 & 20.70 & 31.35 & 2.60 & 33.66 & 27.03 & 24.80 & 11.46 & 4.64 & 14.90 \\
\hline LP 9637 & 2882 & 2424 & 2632 & $2665^{f D}$ & 13.35 & 5.88 & 11.51 & 10.68 & 31.70 & 2.41 & 15.93 & 17.98 & 2.35 & 9.36 & 2.68 & 4.00 \\
\hline Princesa & 2408 & 2348 & 2473 & 2418 & 42.66 & 9.44 & 21.78 & 25.83 & 74.00 & 1.39 & 29.22 & 37.96 & 23.82 & 17.51 & 6.92 & 16.30 \\
\hline $\begin{array}{l}\text { FT-Porto } \\
\text { Real }\end{array}$ & 2550 & 2259 & 2695 & 2531 & 32.24 & 11.33 & 9.68 & 17.95 & 69.19 & 9.79 & 12.69 & 27.14 & 10.07 & 12.89 & 3.65 & 9.54 \\
\hline FT-Nobre & 2494 & 2483 & 2410 & 2458 & 35.91 & 2.69 & 27.62 & 24.00 & 61.25 & 3.16 & 38.85 & 38.29 & 20.71 & 2.22 & 5.15 & 10.90 \\
\hline IAC-Una & 2225 & 2102 & 2435 & 2286 & 57.00 & 17.87 & 25.87 & 34.61 & 99.19 & 21.00 & 26.10 & 45.27 & 31.68 & 14.75 & 25.42 & 24.84 \\
\hline FT-901909 & 2270 & 2201 & 2516 & 2348 & 77.59 & 21.35 & 21.43 & 40.94 & 190.27 & 18.95 & 18.63 & 66.03 & 9.98 & 23.76 & 27.03 & 17.95 \\
\hline LP 9672 & 2467 & 2134 & 2503 & 2394 & 47.14 & 21.24 & 18.24 & 29.08 & 103.73 & 15.17 & 24.71 & 44.14 & 13.20 & 27.31 & 5.29 & 15.27 \\
\hline MA-733327 & 2749 & 2346 & $2785^{f B}$ & $2658^{f B}$ & 11.69 & 7.78 & 7.79 & 9.15 & 15.10 & 5.84 & 11.39 & 10.70 & 9.64 & 9.72 & 0.60 & 7.73 \\
\hline $\begin{array}{l}\text { LM-932042 } \\
-17\end{array}$ & 2408 & 2379 & 2571 & 2464 & 49.74 & 7.73 & 15.90 & 25.54 & 100.58 & 1.54 & 23.26 & 40.54 & 19.23 & 13.94 & 1.17 & 11.79 \\
\hline Overall mean & 2496 & 2263 & 2473 & 2425 & & & & & & & & & & & & \\
\hline
\end{tabular}

$f^{\mathrm{D}}$ e $f^{\mathrm{B}}$ : Dunnett test at the 5\%. Significant values was compared to IAC-Carioca (Diverse grain - D) and IAC-Una (Black grain - B) as the standards for grain types. Values in bold indicates the most yield and stable cultivars and lines on each season. 

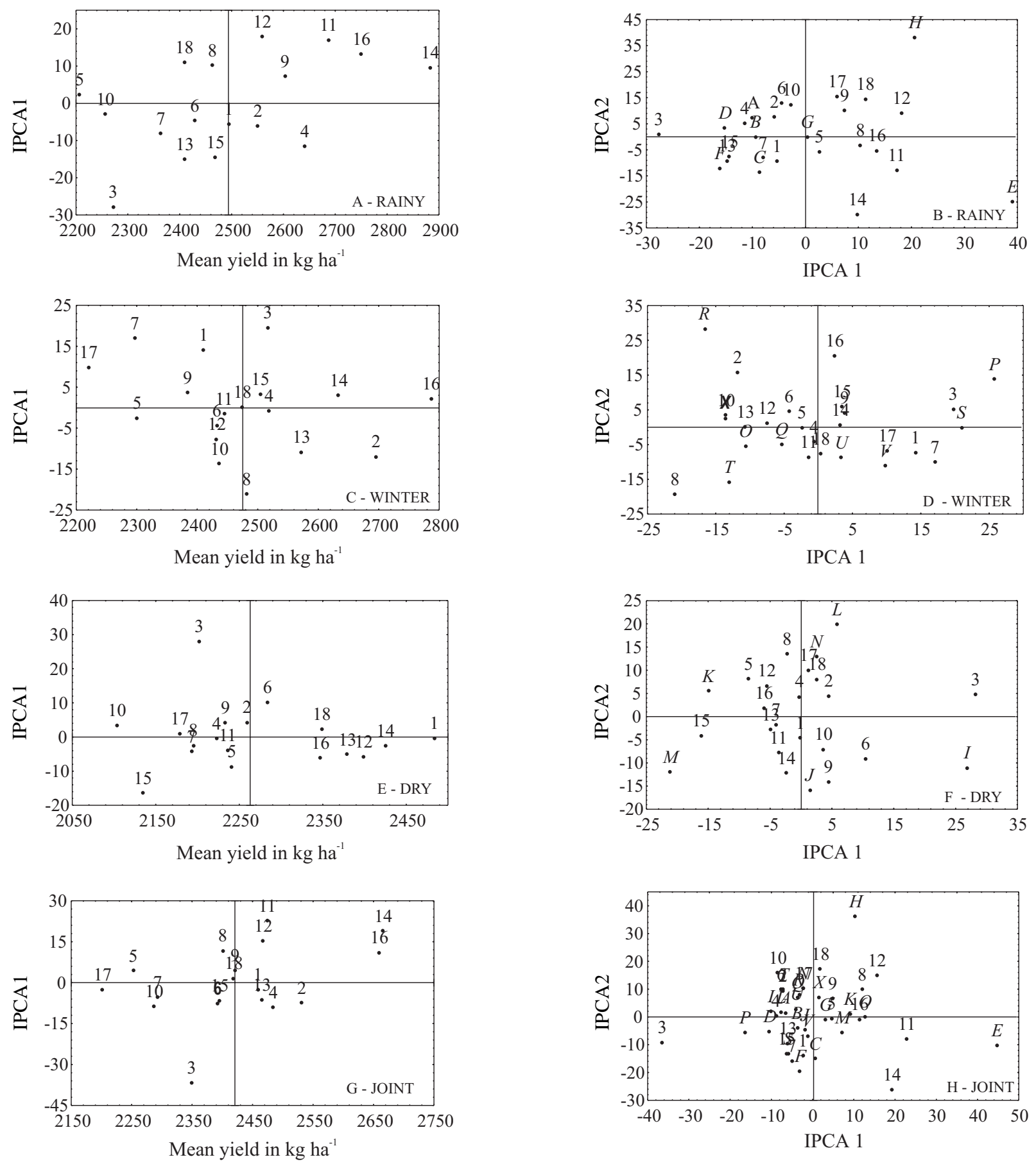

Figure 1- Biplots of the AMMI model for São Paulo state common bean yield trials with 18 cultivars and lines evaluated in rainy, dry and winter seasons and in joint season, for crops 1999 and 2000. Cultivars and environments (seasons) codes are given in Table 1.

stable cultivars and lines. The two latter were also responsive to environmental enhancement and the former presented stability to favorable environments $\left(<\mathrm{P}_{\text {iu }}\right)$. An analysis of the dry season by the AMMI 1 biplot (Figure $1 \mathrm{E})$, with the first axis of the IPCA which accumulates $38.13 \%$ of the $\mathrm{SS}_{\mathrm{GE}}$ and a highly significant $\mathrm{F}_{\mathrm{r}}$ test (Table 2) for AMMI 2 (absorption of $61.09 \%$ of the $\mathrm{SS}_{\mathrm{GE}}$ ), identified the cultivars and lines Princesa (18), LM93204217 (13), LP 9637 (14), and FT-Nobre (1) as most stable and productive, both in increasing order. The combination of the percentage with the significance of the $F_{r}$ test is more important than the percentage magnitude of the interaction absorption by the first principal component for the graphic representation. In case the $\mathrm{F}_{\mathrm{r}}$ test should already be significant for the first and second axis, the AMMI biplots 1 and 2 would be less distorted, despite the low percentage value. Again, both methods are remarkably congruent and identify two most stable and pro- 
ductive cultivars in common. The most differentiating environments (Figure 1F) were Capão Bonito-Dry-1999 (I), Capão Bonito-Dry-2000 (J), Adamantina2-2000 (L), and Espírito Santo do Pinhal-Dry-2000 (M).

In winter, models AMMI 1 and AMMI 2 absorbed $36.99 \%$ and $58.05 \%$ of the $\mathrm{SS}_{\mathrm{GE}}$, respectively. The lines GenC97-2 (4), MA-733327 (16), and LP 9637 (14) were identified as most stable and productive. The MYD method (Table 3) also presented 'MA733327', 'FT- Porto Real', and 'LP 9637' as most stable and responsive to environmental improvement. Cultivar FT-Nobre (1) and lines GenC97-10 (7) and PF-902998 (17) presented specific adaptation to the environment Adamantina 4-2000 $(V)$. Likewise, FT-901909 (3) and MA-733327 (16) indicated specific adaptation to the environments of Votuporanga-1999 (P) and Pindorama-1999 (S), respectively. Other specific adaptations were 'IAC-Carioca' (8) to the Pindorama-2000 environment (T), and 'FT-Porto Real' (2) to Pindamonhangaba-1999 $(R)$. The environments Votuporanga-1999 $(P)$ and Pindorama-1999 $(S)$ are close in the biplot, evidencing similarity, possibly because they are located in similar edaphoclimatic regions. Adamantina 3-2000 $(U)$ and Adamantina 4-2000 (V), close in the biplot, are environments which are only separated by a difference of 30 days in the sowing season (Figure 1D).

This whole differential behavior in relation to the adaptability and stability and to the responsiveness of cultivars and lines in the sowing seasons is probably caused, according to Carbonell et al. (2001), by the presence or absence of pathogens and, in some cases, their physiological races, in different seasons. The response of these cultivars and lines under high temperatures also influenced the mean productivities observed in this study. Dias (1998) claims that the selection of most productive and stable genotypes is an indirect form of accessing the disease resistance of cultivars and lines. In this situation, resistance is seen as a protection against production loss, from the point of view that resistant cultivars and lines would be the most productive and stable and, therefore, presenting a smaller yield loss. The same train of thought can be extended to resistance to high temperatures during the dry season.

The applied methods of adaptability and stability (MYD and AMMI) presented considerable congruence, since they identified the same cultivars and lines as stable. MYD, however, invariably identified the most stable cultivars and lines as most productive also, a fact which was not always verified by AMMI. The reason is that MYD identifies the most stable cultivars and lines as those with the smallest deviation from the highest mean productivity in each environment. This procedure agrees to the most recent understanding of adaptation, according to which an adapted cultivar/line has the highest economic production (Ceccarelli, 1996). For AMMI, the clas- sification of the cultivars and lines for stability and productivity was only the same in the dry season. On the other hand, Gonçalves (1997) did not observe any similarity between MYD and AMMI applied to maize, and ascribed this to the small absorption of the interaction variation by the first axis of the IPCA, in this case, $45.8 \%$. The relative agreement between the methods was obtained with absorption percentages varying from $26.20 \%$ (joint seasons) to $38.80 \%$ (rainy season) of $\mathrm{SS}_{\mathrm{GE}}$.

\section{CONCLUSIONS}

The analyses of adaptability and stability processed by the MYD and AMMI methods identified lines MA-733327 and LP 9637 as the most stable and responsive to the environmental enhancement for the rainy and winter seasons together. 'LP 9637' and 'FT-Nobre' were the most stable in the dry season. The first two were also the most productive and are the recommended for the State of São Paulo. MYD and AMMI produced similar results, in terms of the order of the most stable cultivars and lines. The MYD method combined a simple procedure, easiness of result interpretation, uniqueness of parameters, and parallelism between stability and yield, though it provides little information on the evaluated environments. The AMMI method comes up for this aspect with a biplot of clear visual display. Furthermore, AMMI is a relative complex method, and requires knowledge on advanced statistics from the breeder, or help of a biometrist.

\section{ACKNOWLEDGEMENTS}

To IAC and other Departments of APTA, Cooperatives and farmers for their help with the set up of the experiments; to FAPESP and CNPq for financial support; to professor João Batista Duarte, of Universidade Federal de Goiás for the AMMI analyses.

\section{REFERENCES}

ABREU, A.F.B.; RAMALHO, M.A.P.; SANTOS, J.B. Desempenho e estabilidade fenotípica de cultivares de feijão em algumas localidades do Estado de Minas Gerais no período de 1989-1991. Ciência e Prática, v.16, p.18-24, 1992

CARBONELL, S.A.M.; POMPEU, A.S. Estratificação de ambientes em experimentos de feijoeiro no Estado de São Paulo. Bragantia, v.56, p.207-218, 1997.

CARBONELL, S.A.M.; POMPEU, A.S. Estabilidade fenotípica de linhagens de feijoeiro em três épocas de plantio no Estado de São Paulo. Pesquisa Agropecuária Brasileira, v.35, p.321-329, 2000.

CARBONELL, S.A.M.; AZEVEDO FILHO, J.A.; DIAS, L.A.S.; GONÇALVES, C.; ANTONIO, C.B. Adaptabilidade e estabilidade de produção de cultivars e linhagens de feijoeiro no Estado de São Paulo. Bragantia, v.60, p.69-77, 2001

CARNEIRO, P.C.S. Novas metodologias de análise da adaptabilidade e estabilidade de comportamento. Viçosa: UFV, 1998. 155p. (Tese Doutorado)

CECCARELLI, S. Adaptation to low/high input cultivation. Euphytica, v.92, p.203-214, 1996 
COCHRAN, W.G. The combination of estimates from different experiments. Biometrics, v.10, p.101-129, 1954.

CORNELIUS, P.L.; SEYEDSADR, M.S.; CROSSA, J. Using the shifted multiplicative model to search for 'separability' in crop cultivar trial. Theoretical and Applied Genetics, v.84, p.161-172, 1992.

CRUZ, C.D. Programa Genes: versão Windows; aplicativo computacional em genética e estatística. Viçosa: UFV, 2001. 648p.

CRUZ, C.D.; TORRES, R.A.; VENCOVSKY, R. An alternative approach to the stability analysis proposed by Silva e Barreto. Revista Brasileira de Genética, v.12, p.567-580, 1989.

DIAS, L.A.S. Novos rumos no melhoramento genético do cacaueiro. In: SIMPÓSIO SOBRE ATUALIZAÇÃO EM GENÉTICA E MELHORAMENTO DE PLANTAS, 3., Lavras, 1998. Anais. Lavras: UFLA, Núcleo de Estudos de Genética, 1998. p.9-27.

DUARTE, J.B.; VENCOVSKY, R.. Interação genótipos x ambientes: uma introdução à análise "AMMI". Ribeirão Preto: Sociedade Brasileira de Genética, 1999. 60p. (Série Monografias, 9).

DUARTE, J.B.; ZIMMERMANN, M.J. Selection of location for common bean (Phaseolus vulgaris L.) germplasm evaluation. Revista Brasileira de Genética, v.14, p.765-770, 1991.

GAUCH, H.G.; ZOBEL, R.W. AMMI analysis of yield trials. In: KANG, M.S.; GAUCH. H.G. (Ed.) Genotype by environment interaction. Boca Raton: CRC Press, 1996. cap.4, p.85-122.

GONÇALVES, F.M.A. Adaptabilidade e estabilidade de cultivares de milho avaliadas em "safrinha" no período de 1993 a 1995. Lavras: UFLA, 1997. 98p. (Dissertação - Mestrado).
LIN, C.S.; BINNS, M.R. A superiority measure of cultivar performance for cultivar $x$ location data. Canadian Journal of Plant Science, v.68, p.193-198, 1988.

PIEPHO, H.P. Robustness of statistical test for multiplicative terms in the additive main effects and multiplicative interaction model for cultivar trial. Theoretical and Applied Genetics, v.90, p.438-443, 1995.

PINZAN, N.R.; BULISANI, E.A.; BERTI, A.J. Feijão: zoneamento ecológico e épocas de semeadura para o Estado de São Paulo. Campinas: CATI, 1994. 19p. (Boletim Técnico, 218).

RAMALHO, M.A.P.; ABREU, A.F.B.; RIGHETTO, G.U. Interação de cultivares de feijão por épocas de semeadura em diferentes localidades do Estado de Minas Gerais. Pesquisa Agropecuária Brasileira, v.28, p.1183-1189, 1993.

SAS INSTITUTE. SAS/STAT user's guide: version 6. 4.ed. Cary: Statistic Analysis System, 1989. v.2, 846p.

WEBER, W.E.; WRICKE, G.; WESTERMANN, T. Selection of genotypes and prediction on performance analyzing genotype-by-environment interactions. In: KANG, M.S.; GAUCH, H.G. (Ed.) Genotype by environment interaction. Boca Raton: CRC Press, 1996. cap.13, p.353371 .

Received October 04, 2002

Accepted December 12, 2003 